\title{
PEMBELAJARAN YANG MULTIKULTURAL UNTUK MEMBANGUN KARAKTER BANGSA
}

\author{
Yudi Hartono ${ }^{1}$ )
}

\begin{abstract}
Abstrak
Masyarakat Indonesia yang majemuk memerlukan pendidikan yang multikultural. Pendekatan multikultural harus diperhatikan oleh para pengembang kurikulum dan pembelajaran. Pembelajaran sejarah yang multikultural juga menjadi semakin penting di tengah tantangan yang dihadapi masyarakat Indonesia saat ini.. Kurikulum dan praksis pembelajaran sejarah yang multikultural adalah kurikulum dan pembelajaran yang mengakomodasi perbedaan latar belakang sejarah, memanfaatkan kebudayaan sebagai sumber muatan dan titik berangkat bagi pengembangan kebudayaan itu sendiri, pemahaman terhadap kebudayaan orang lain, toleransi, membangkitkan semangat kebangsaan dan mengembangkan perilaku yang lebih beretika serta memanfaatkan kebudayaan peserta didik sebagai bagian dari pembangunan peserta didik. Dengan cara demikian, pembelajaran sejarah diharapkan akan semakin dapat berperan bagi pembangunan karakter bangsa.
\end{abstract}

Kata kunci: Pendekatan Multikultur, Pembelajaran Sejarah

1) Yudi Hartono adalah Dosen Pendidikan Sejarah IKIP PGRI Madiun; Jl Setiabudi 85 Madiun; email: cahya_nadwa@yahoo.com. 


\section{Pendahuluan}

Indonesia merupakan sebuah negara kepulauan dengan keragaman suku, bahasa, adat istiadat dan agama. Ribuan pulau besar dan kecil tersebar dipermukaan laut. Hasil penelitian TNI-AL pada tahun 2006 menunjukkan terdapat 17.508 pulau dengan gugusan pulau-pulau besar dan kecil. Sejumlah 6.044 pulau diantaranya sudah bernama, sedangkan lainnya belum dikenal. Data lain menunjukkan bahwa jumlah pulau Indonesia besar dan kecil adalah 17.670, dan terdapat lebih kurang 665 bahasa daerah dan 300 suku bangsa (Moeis, 2006), sedangkan berdasarkan potret satelit yang disiarkan oleh Radio Nederland 19 Februari 2003, jumlah pulau milik Indonesia 18.108 buah, bertambah dari selama ini yang diperkirakan antara 13.000 sampai 17.000 pulau. Perkiraan jumlah pulau milik Indonesia masih menjadi bahan perdebatan.

Ribuan pulau tersebut terbentang dari Aceh hingga Papua sejauh $6.400 \mathrm{~km}$ dan sekitar 2.500 $\mathrm{km}$ jarak antara utara dan selatan. Garis terluar yang mengelilingi wilayah Indonesia sepanjang kurang lebih $81.000 \mathrm{~km}$ dan sekitar 80 persennya adalah laut. Pulau-pulau besar yang menjadi bagian dari wilayah Indonesia adalah Sumatra, Jawa, sekitar tiga perempat Kalimantan, Sulawesi, kepulauan Maluku dan pulau-pulau kecil di sekitarnya, serta separuh bagian barat dari Papua.
Faktor geografis yang terdiri dari ribuan pulau berpengaruh besar terhadap terciptanya pluralitas suku bangsa di Indonesia. Diversivitas mengakibatkan isolasi budaya, walaupun budaya dari pulau-pulau yang berbeda mempunyai akar yang sama. Penyebab perbedaan itu dapat ditemukan pada etnik (Wertheim, 1999). Setiap satuan etnik terdiri dari sejumlah orang yang dipersatukan oleh ikatan emosional serta memandang diri mereka sebagai suatu jenis tersendiri. Dengan perkecualian yang sangat kecil, mereka pada umumnya memiliki bahasa dan warisan kebudayaan yang sama. Lebih daripada itu, mereka biasanya mengembangkan kepercayaan bahwa mereka memiliki asal-usul keturunan yang sama, suatu kepercayaan yang seringkali didukung oleh mitos-mitos yang hidup di dalam masyarakat (Shibutani dalam Nasikun, 1986).

Berbagai etnis di Indonesia memiliki budayanya masing-masing. Di Pulau Sumatra: Aceh, Batak, Minang, Melayu (Deli, Riau, Jambi, Palembang, Bengkulu, dan sebagainya), Lampung; di Pulau Jawa: Sunda, Badui (masyarakat tradisional yang mengisolasi diri dari dunia luar di Provinsi Banten), Jawa, dan Madura; Bali; Nusa Tenggara Barat dan Nusa Tengara Timur: Sasak, Mangarai, Sumbawa, Flores, dan sebagainya; Kalimantan: Dayak, Melayu, Banjar dan sebagainya; Sulawesi: Bugis, Makassar, Toraja, Gorontalo, Minahasa, Manado, dan sebagainya.; Maluku: Ambon, Ternate, dan 
sebagainya; Papua: Dani, Asmat, dan sebagainya (Koentjaraningrat, 2002). Kelompok etnis masih dapat digolongkan berdasarkan sistem kepercayaan, adat istiadat, sistem kekerabatan, dan sebagainya.

Keberadaan satuan-satuan etnis tersebut telah ada jauh sebelum zaman modern. Tome Pires pada sekitar tahun 1500 menemukan puluhan kelompok etnis. Masingmasing mempunyai perkampungan sendiri dan jelas-jelas menunjukkan otonominya sebagai kesatuan. Banyak nama etnik sama dengan nama daerahnya, bahkan sekaligus menunjukkan nama kebudayaannya.

Antropolog Hildred Geertz (1981) mencatat lebih dari 300 kelompok suku dengan identitas kebudayaan tersendiri dan lebih dari 250 bahasa daerah yang khas. Kepercayaan agama juga bermacammacam. Hampir semua agama dunia yang besar dan penting ada di kepulauan Indonesia. Agama-agama tersebut adalah Islam, Kristen, Katolik, Hindu, Budha, dan Kong Hu $\mathrm{Cu}$.

Skinner (1959) menyebutkan adanya lebih dari 35 suku bangsa di Indonesia, masing-masing dengan bahasa dan adat yang tidak sama. Skinner juga menggambarkan perbandingan besarnya sukubangsasukubangsa tersebut. Beberapa sukubangsa yang tergolong paling besar adalah Jawa, Sunda, Madura, dan Bugis. Nasikun (1986) memasukan Tionghoa ke dalamnya. Sekalipun jumlahnya tidak seberapa besar, namun kedudukan mereka yang sangat kuat di dalam bidang ekonomi berpengaruh besar dalam hubungan dengan sukubangsa yang lain, yang sebagai keseluruhan biasanya dipandang sebagai golongan pribumi.

Ditinjau dari segi bahasa, ada sekitar 726 bahasa daerah yang tersebar di seluruh Nusantara, mulai dari penutur yang hanya berjumlah belasan orang, seperti bahasa di Papua, sampai dengan penutur yang berjumlah puluhan juta orang, seperti bahasa Jawa dan Sunda. Suku bangsa dan etnis itu adakalanya menempati daerah atau wilayah dalam sebuah provinsi dan adakalanya menempati lintas provinsi. Etnis Jawa misalnya, menempati tiga provinsi, yakni Provinsi Jawa Tengah, Jawa Timur, dan Daerah Istimewa Yogyakarta. Walaupun begitu, suku Jawa tersebar ke seluruh pelosok Indonesia, bahkan sampai ke Suriname. Di setiap daerah itu terdapat pula sub-sub etnis dengan sub budaya yang berbeda pula seperti Solo dan Yogyakarta sampai ke Banyuwangi Jawa Timur. Umumnya orang Indonesia mengenal bahwa orang Solo dan Daerah Istimewa Yogyakarta sering dikatakan sebagai masyarakat yang memiliki budaya yang halus, tutur sapa yang lembut, dan budi bahasa yang santun. Hal itu menandai keunggulan budayanya. Akan tetapi, tidak jarang pula masyarakat daerah tertentu yang berbicara dan bersikap keras, namun pada hakikatnya hatinya lembut (Ruskhan, 2007).

Selain kondisi geografis sebagai negara kepulauan, kenyataan lain adalah bahwa Indonesia terletak di antara Samudera Indonesia dan Pasifik. Kondisi ini mempengaruhi terciptanya pluralitas agama 
masyarakat Indonesia. Sejak lama masyarakat Indonesia memperoleh berbagai pengaruh kebudayaan bangsa lain melalui para pedagang asing. Hasil final dari semua pengaruh itu dapat dijumpai dalam bentuk pluralitas agama.

Denys Lombard dalam penelitiannya (1996) mengungkapkan bahwa Indonesia berada dalam persimpangan pengaruh budaya internasional. Oleh sebab itu, bangsa Indonesia bukan hanya terdiri dari berbagai suku, tetapi juga dengan berbagai jenis kebudayaan sesuai dengan pengaruh-pengaruh kebudayan dunia yang telah memasuki Indonesia sejak berabad-abad lalu. Kebudayaan Indonesia terdiri dari lapisan-lapisan budaya dengan ciriciri khas yang telah memasuki dan berintegrasi dalam budaya lokal. Pengaruh-pengaruh budaya tersebut telah membentuk mozaik kebudayaan yang sangat kaya dan bervariasi sama dengan keanekaragaman hayati yang dimiliki oleh tumpah darah Indonesia yang kaya raya.

Menurut Sartono Kartodirdjo (1999) kemajemukan masyarakat Indonesia dapat dikenali jauh ke masa lampau, tidak hanya ke zaman Sriwijaya dan Majapahit, melainkan juga sejak masa prasejarah. Proses itu disimpulkan dari distribusi nekara (moko), bahasa Melayu, rute perdagangan dan navigasi. Kesemuanya ini telah menunjukkan adanya pengalaman bersama proses integrasi bangsa Indonesia.

Kemajemukan masyarakat Indonesia dapat diterima sebagai fakta deskriptif. Namun secara preskriptif, dalam beberapa kasus, kemajemukan itu sering dianggap sebagai faktor penyulit yang serius, terutama dalam satu dekade terakhir saat konflik horisontal merebak di banyak daerah. Kekerasan antarkelompok yang meledak secara sporadis di berbagai kawasan di Indonesia menunjukkan betapa rentannya rasa kebersamaan yang dibangun dalam negara-bangsa, betapa kentalnya prasangka antarkelompok dan betapa rendahnya saling pengertian dan toleransi atas keragaman.

Pendidikan berperan penting dalam upaya membangun toleransi atas keragaman. Pendidikan sebagai media penyemai nilai-nilai menjadi semakin penting peranannya dalam membangun tata kehidupan yang lebih baik. Ricklefs (1998) menyebutkan bahwa pendidikan dan media umum telah memperkokoh ikatan rakyat dan Negara Indonesia secara umum. Namun pernyataan ini perlu dikaji lebih lanjut berkaitan dengan posisi pendidikan dalam memantapkan kemampuan bangsa Indonesia dalam mengelola keragaman dan beradaptasi dengan pengaruh budaya-budaya besar dewasa ini.

Dalam kondisi masyarakat Indonesia saat ini yang rentan dengan konflik antarkelompok, maka pendidikan multikultural menjadi semakin penting keberadaannya. Pendidikan yang bercirikan multikultural adalah pendidikan yang melayani kepentingan masyarakat dari berbagai latar belakang budaya (Fuad Abdul Hamid, 1994). Pendidikan multikultural merupakan pendidikan yang berwawasan ke- 
ragaman kebudayaan menjadi materi pelajaran dan wawasan pembelajaran yang harus diperhatikan oleh para pengembang kurikulum.

Dalam konteks di atas, pembelajaran sejarah dengan pendekatan multikultural juga menjadi penting. Banyak pihak telah mengkritisi pembelajaran sejarah di Indonesia. Niels Mulder (1997) mensinyalir bahwa pembelajaran sejarah dikuasai oleh negara. Sejarah menjadi sesuatu yang beku, penjelmaan suatu "ideologi" dan penuh dengan fakta yang pantas diketahui atau sekurangkurangnya layak dihafalkan menurut pendapat orang yang menciptakan sejarah semacam itu. Hal ini disebabkan oleh obsesi pemerintah dengan persatuan dan kesatuan dan paranoia yang disebabkan oleh keanekaragaman. Monokulturalisme dalam pembelajaran sejarah berakibat pada kurangnya pemahaman peserta didik terhadap kekayaan sejarah dan keragaman masyarakat Indonesia.

Monokulturalisme mengakibatkan rentannya hubungan antarkelompok. Berbagai konflik berdarah meletus yang melibatkan sentimen etnis, golongan, dan juga agama, seperti di Poso, Ambon, Maluku Utara, Pontianak, Sampit, Solo, dan berbagai tempat lainnya. Berbagai konflik tersebut mengindikasikan kerentanan hubungan antarkelompok di Indonesia. Konflik antaretnik ataupun antaragama yang terjadi di beberapa daerah di Indonesia menggambarkan bahwa interaksi, relasi, dan komunikasi antarmanusia pada semua level baik antarpribadi, kelompok, komunitas bahkan antar- bangsa tidak selalu berjalan sebagaimana yang diharapkan.

Konflik yang berkenaan dengan hubungan sosial antarkelompok dapat disebabkan oleh lemahnya pemahaman tentang konsep kearifan budaya, tidak ada distribusi nilai yang adil kepada masyarakat, dan adanya prasangka rasial. Prasangka rasial dapat disebabkan oleh situasi sosial, sejarah masa lalu, stereotip, dan etnosentrisme yang menjadi bagian dalam kebudayaan kelompok tertentu. Sikap prasangka etnik rasial, baik yang menyangkut agama maupun budaya bisa menjadi penghambat dalam interaksi serta pergaulan antar sukubangsa dan pemeluk agama bahkan bisa menimbulkan konflik.

Berbagai konflik horizontal memperlihatkan bahwa bangsa Indonesia sedang menghadapi bahaya disintegrasi nasional. Masyarakat majemuk yang mencoba membangun demokrasi secara lebih baik, menurut Makarim (2000) akan mengalami masa-masa krisis. Masyarakat yang sedang dalam krisis biasanya kehilangan pegangan, rasa percaya diri melemah, dan kepercayaan kepada pemerintah menurun tajam.

Cipto dkk (2002) mengemukakan bahwa setidaknya terdapat delapan fenomena patologi sosial yang tersisa dari proses transisi, yaitu hancurnya nilai-nilai demokrasi dalam masyarakat, memudarnya kehidupan kewargaan dan nilai-nilai komunitas, kemerosotan nilai-nilai toleransi dalam masyarakat, memudarnya nilai-nilai kejujuran, kesopanan, dan rasa tolong-menolong, 
melemahnya nilai-nilai dalam keluarga, praktek korupsi, kolusi, nepotisme dalam penyelenggaraan pemerintahan, kerusakan sistem dan kehidupan ekonomi, dan pelanggaran terhadap nilai-nilai kebangsaan.

Di masa kritis yang dilewati oleh bangsa Indonesia dengan terjadinya berbagai konflik horisontal menunjukan gejala-gejala pengkhianatan terhadap tiga asas kehidupan masyarakat bangsa Indonesia yaitu: Pertama, pengkhianatan terhadap Sumpah Pemuda tahun 1928, yaitu keinginan untuk membangun satu bangsa, yaitu bangsa Indonesia. Kedua, pengkhianatan terhadap kesepakatan untuk hidup bersama di bawah payung Negara Kesatuan Republik Indonesia, terlihat dari gejala-gejala separatisme untuk memisahkan diri dari Negara Kesatuan Republik Indonesia. Gerakan ini tentunya lahir karena kekhilafankekhilafan yang kita buat, antara lain dengan meremehkan eksistensi kebhinekaan budaya bangsa Indonesia dan terlalu mementingkan budaya dari satu-dua kelompok etnis saja. Ketiga, penghianatan terhadap ikrar bersama untuk hidup rukun, penuh toleransi, karena diikat oleh satu tujuan, yaitu ingin membangun satu masyarakat yang adil dan makmur untuk seluruh masyarakat (Magnis Suseno dalam H.A.R. Tilaar, 2002).

Nasionalisme Indonesia menghadapi tantangan yang cukup berat. Ikatan-ikatan yang sebelumnya terpatri kuat dalam sebuah titik pandang sama dalam sebuah negara bangsa (nation state), kini berkembang dalam kesadaran etnis yang terus meningkat. Bahkan kesadaran etnis tersebut telah mengakibatkan sentimen berlebihan dengan tuntutan merdeka dari beberapa daerah, terutama sejak diberlakukannya otonomi dan desentralisasi.

Sebagai ideologi, nasionalisme dapat memiliki tiga fungsi, yaitu mengikat semua kelas, menyatukan mentalitas, dan membangun atau memperkokoh pengaruh terhadap kebijakan yang ada di dalam ideologi nasional (Hertz dalam Karim, 1996). Djoko Santoso (2008) mengingatkan bahwa melemahnya semangat nasionalisme atau nasionalisme Indonesia disebabkan oleh beberapa permasalahan antara lain (1) kualitas sumber daya manusia yang masih rendah; (2) militansi bangsa yang mendekati titik kritis; dan (3) jati diri bangsa Indonesia yang sudah luntur. Menghadapi berbagai permasalahan tersebut, apabila tidak ada upaya yang sungguh-sungguh, tidak menutup kemungkinan disintegrasi bangsa dapat menjadi ancaman aktual yang berpengaruh terhadap integritas dan kedaulatan NKRI. Pembelajaran sejarah dengan pendekatan multikultural, dengan demikian, menjadi penting untuk menjawab persoalan-persoalan tersebut.

\section{Pendekatan Multikultural Dalam Pendidikan}

Pada masyarakat majemuk terdapat kecenderungan munculnya prasangka yang dapat mempengaruhi interaksi sosial. Prasangka tersebut bisa merupakan warisan 
generasi sebelumnya ataupun muncul sebagai gejala baru. Berbagai prasangka sosial tersebut umumnya tidak bersifat langgeng, melainkan bisa berubah. Perubahan prasangka dapat menuju interaksi sosial yang lebih baik atau lebih buruk. Perubahan ini ditentikan oleh cara berbagai entitas di dalam suatu masyarakat majemuk mengelola prasangka-prasangka sosial yang ada dalam diri masing-masing.

Pendidikan multikultural merupakan upaya kolektif suatu masyarakat majemuk untuk mengelola berbagai prasangka sosial yang ada dengan cara-cara yang baik. Tujuannya adalah untuk menciptakan hubungan lebih serasi dan kreatif di antara berbagai golongan penduduk. Melalui pendidikan multikutural, siswa yang datang dari berbagai latar belakang dibimbing untuk saling mengenal cara hidup mereka, adat-istiadat, kebiasaan, memahami aspirasi-aspirasi mereka, serta untuk mengakui dan menghormati bahwa tiap golongan memiliki hak untuk menyatakan diri menurut cara masing-masing (Mochtar Buchori, 2007).

Pendidikan multikultural sangat penting diterapkan guna meminimalisasi dan mencegah terjadinya konflik di beberapa daerah. Melalui pendidikan berbasis multikultural, sikap dan pemikiran peserta didik akan lebih terbuka untuk memahami dan menghargai keberagaman. Dengan pengembangan model pendidikan berbasis multikultural, menurut H.A.R. Tilaar (2007), diharapkan mampu menjadi salah satu metode efektif meredam konflik.
Selain itu, pendidikan multikultural bisa menanamkan sekaligus mengubah pemikiran peserta didik untuk benar-benar tulus menghargai keberagaman etnis, agama, ras, dan antargolongan.

Masyarakat yang multikulural memerlukan suatu paradigma pendidikan nasional yang bercirikan multikultural, yaitu pendidikan yang melayani kepentingan masyarakat dari berbagai latar belakang budaya (Fuad Abdul Hamid, 1994). Menurut Mochtar Buchori, pendidikan multikultural diselenggarakan sebagai sarana melahirkan proses integrasi. Pendidikan mutikultural akan melahirkan proses integrasi bangsa yang sehat, dan melahirkan identitas bangsa yang sesuai dengan perkembangan zaman (Mochtar Buchori, 2007).

Masyarakat Indonesia yang multikultural dan rentan dengan konflik antarkelompok memerlukan pendidikan dengan pendekatan multikultural. Pendidikan multikultural relevan dengan pengembangan demokrasi yang dijalankan sebagai respon terhadap kebijakan desentralisasi dan otonomi daerah. Pendidikan multikultural semakin penting keberadaannya di tengah perubahan-perubahan yang begitu cepat dan dramatis karena globalisasi yang semakin meningkat. Perubahan-perubahan itu bersifat mondial, spektakuler, dan terkadang kurang memberi kesempatan kepada kita untuk menyiapkan diri dalam menghadapinya.

Pendidikan yang bercirikan multikultural adalah pendidikan yang melayani kepentingan masya- 
rakat dari berbagai latar belakang budaya. Pendidikan multikultural merupakan pendidikan yang berwawasan keragaman kebudayaan keragaman kebudayaan menjadi materi pelajaran dan wawasan pembelajaran yang harus diperhatikan oleh para pengembang kurikulum dan pembelajaran.

Kurikulum yang multikultural adalah kurikulum yang mengakomodasi perbedaan kultural peserta didik, memanfaatkan kebudayaan sebagai sumber muatan dan titik berangkat bagi pengembangan kebudayaan itu sendiri, pemahaman terhadap kebudayaan orang lain, toleransi, membangkitkan semangat kebangsaan peserta didik dan mengembangkan perilaku yang lebih beretika. Tidak kalah pentingnya adalah memanfaatkan kebudayaan peserta didik sebagai bagian dari pembangunan peserta didik (Fuad Abdul Hamid, 1994).

Pendidikan multikultural relevan untuk membangun nasionalisme Ke-Indonesia-an dalam menghadapi tantangan global, karena memiliki nilai inti dalam perspektif lokal maupun global, yaitu:

1) Ketakwaan terhadap tuhan Yang Maha Esa;

2) Tanggung jawab terhadap negara kesatuan;

3) Penghargaan, pengakuan, dan penerimaan keragaman budaya;

4) Menjunjung tinggi supremasi hukum; dan

5) Penghargaan martabat manusia dan hak asasi yang universal.

Pendidikan multikultural mempunyai tujuan yang selaras dengan upaya membangun nasionalisme Ke-
Indonesia-an dalam menghadapi tantangan global. Tantangan yang dihadapi pendidikan multikultural menurut Sparringa (2003) meliputi:

a) Bagaimanakah masalah kesadaran bersama itu dibangun dalam sebuah ruang yang memberikan kebebasan untuk melakukan interpretasi yang serba ragam dan juga mengundang eleven-elemen yang berbeda untuk menemukan kebutuhan bersama bagi sebuah integrasi di tingkat yang lebih tinggi;

b) Proses pendidikan multikultural tidak terjadi pada ruang yang terisolasi dari persoalan-persoalan ketidakmerataan, bahkan ketidakadilan, tentang bagaimana sumber-sumber politik dan ekonomi itu dialokasikan dan distribusikan dalam masyarakat nasional dan internasional;

c) Perubahan yang berlangsung di tataran global mendiktekan agenda-agenda politik dan ekonomi baru yang mempersempit kesempatan kita untuk mendefinisikan kembali gagasan-gagasan dasar tentang negara bangsa tanpa mengindahkan gagasan-gagasan dan praktik-praktik materialisme rasional yang dibawa serta oleh ekonomi pasar global.

Multikulturalisme mengembangkan sikap hidup yang terbuka dan toleran. Tertanamnya kesadaran multikultural akan menghasilkan corak kehidupan yang terbuka dan toleran. Sikap hidup yang ekslusif dan intoleran akan mengganggu harmonisasi masyarakat. Dengan demikian, melintasi batas menjadi penting bagi masyarkat yang multi- 
kultur seperti Indonesia. Tantangan masyarakat yang multikultur adalah bagaimana membangun toleransi dan pengertian antarkelompok, sehingga akan tercipta hidup damai. Disinilah urgensi pendidikan multikultural dan lintas budaya untuk dapat menumbuhkan pola pikir, sikap, dan perilaku yang menghargai dan menghormati keragaman, sehingga konflik yang mungkin timbul dapat terkelola dengan baik tanpa kekerasan.

Tanpa pendidikan multikultural, konflik sosial yang destruktif akan terus menjadi suatu ancaman serius bagi keutuhan dan persatuan bangsa. Pendidikan multikultural tidak hanya memberi kesempatan anak didik memahami budaya, suku, agama lain, dan kemudian mampu merajut toleransi, tetapi lebih mendalam lagi yakni anak didik mampu mengerti disparitas kesenjangan sosial seperti ketidakadilan, kemiskinan, penindasan di sekitarnya, dan mampu melakukan aksi-aksi yang nyata (Tilaar, 2006).

Pendidikan multikultural penting untuk membangun kohesifitas, soliditas, dan intimitas diantara keragaman etnik, ras, agama, dan budaya. Melalui penanaman semangat multikulturalisme di sekolah-sekolah akan menjadi media pelatihan dan penyadaran bagi generasi muda untuk menerima perbedaan diantara sesama warga negara dan mau hidup bersama secara damai.

Urgensi pendidikan multikultural secara lebih rinci dapat dikemukakan sebagai berikut. Pertama, bahwa secara alami atau kodrati manusia diciptakan Tuhan dalam keanekaragaman kebudayaan, dan oleh karena itu pembangunan manusia harus memperhatikan keanekaragaman budaya tersebut. Dalam konteks ke-Indonesia-an, maka menjadi keniscayaan bahwa pembangunan manusia Indonesia harus didasarkan atas multikulturalisme mengingat kenyataan bahwa negeri ini berdiri di atas keanekaragaman budaya.

Kedua, bahwa terjadinya konflik sosial yang bernuansa suku, agama, dan ras yang melanda Indonesia pada dasawarsa terakhir berkaitan erat dengan masalah kebudayaan. Dari banyak studi menyebutkan salah satu penyebab utama dari konflik ini adalah akibat lemahnya pemahaman dan pemaknaan tentang konsep kearifan budaya. Konflikkonflik kedaerahan sering terjadi seiring dengan ketiadaan pemahaman akan keberagaman atau multikultur. Oleh karena untuk mencegah atau meminimalkan konflik tersebut perlu dikembangkan pendidikan multikulturalisme.

Ketiga, bahwa pemahaman terhadap multikulturalisme merupakan kebutuhan bagi manusia untuk menghadapi tantangan global di masa mendatang. Pendidikan multikultural mempunyai dua tanggung jawab besar, yaitu menyiapkan bangsa Indonesia untuk siap menghadapi arus budaya luar di era globalisasi dan menyatukan bangsa sendiri yang terdiri dari berbagai macam budaya. Apabila kedua tanggung jawab besar itu dapat dicapai, maka kemungkinan disintegrasi bangsa dan munculnya 
konflik dapat dihindarkan. Konflik antarbudaya yang disebut oleh Samuel P. Huntington (1993) sebagai benturan antar peradaban akan mendominasi politik global. Dalam bukunya yang terkenal, The Clash of Civilization and the Remaking of World Order, Hantington menyebutkan bahwa terjadinya berbagai konflik sosial dan etnis di berbagai belahan dunia antara lain disebabkan oleh perbedaan kebudayaan yang semakin nyata.

\section{Kontribusi Pembelajaran Sejarah bagi Pembangunan Karakter Bangsa}

Para pendiri bangsa telah berhasil membangun bangsa (nation building), namun untuk membangun karakter bangsa masih memerlukan waktu yang panjang. Upaya membangun karakter bangsa mengalami pasang surut sejalan dengan pergulatan bangsa dalam menentukan arah perjuangan dan juga arah pembangunan.

Sebagai negara baru, pada era pasca kemerdekaan, Indonesia diwarnai oleh pergulatan politik, terutama menyangkut persoalan ideologi negara yang akan menentukan wujud dan jatidiri bangsa di masa depan. Mekanisme melalaui Konstituante mengalami jalan buntu sehingga kemudian ditempuh jalan Dekrit Presiden 1959 untuk kembali ke UUD 1945 dan ideologi Pancasila.

Sejak saat itu, semangat untuk membangun kultur dan jatidiri berbasis Pancasila semakin menguat, namun dalam perjalanannya pem- bangunan yang terlalu berorientasi pada materi telah menumbuhkan kultur yang tidak sejalan dengan kultur yang ingin dikembangkan, yaitu kultur Pancasila. Pada masa Orde Baru, keberhasilan pembangunan ekonomi kurang diimbangi dengan pembangunan karakter bangsa. Kebijakan sosial-politik pada saat itu cenderung uniformistik, sehingga tampak budaya kelompok dominan yang diajarkan dan disalurkan melalui sekolah dari satu generasi kepada generasi berikutnya.

Padahal, menurut S. Hamid Hasan, keragaman sosial, budaya, ekonomi, dan aspirasi politik, dan kemampuan ekonomi adalah suatu realitas masyarakat dan bangsa Indonesia. Namun demikian, keragaman sosial, budaya, ekonomi, dan aspirasi politik yang seharusnya menjadi faktor yang diperhitungkan dalam penentuan filsafat, teori, visi, pengembangan dokumen, sosialisasi kurikulum, dan pelaksanaan kurikulum, nampaknya belum dijadikan sebagai faktor yang harus dipertimbangkan dalam pelaksanaan kurikulum pendidikan di negara kita (Hasan, 2000). Akibatnya menjadi wajar ketika terjadi kegagalan dalam pendidikan, terutama dalam menumbuhkan sikap untuk menghargai perbedaan di masyarakat.

Keberhasilan pembangunan ekonomi yang kurang diimbangi dengan pembangunan karakter bangsa telah mengakibatkan goncangan dan krisis budaya, yang kemudian berakibat pada lemahnya ketahanan budaya bangsa. Lemahnya ketahanan budaya tersebut tercermin antara lain dari lemahnya kemampuan dalam me- 
nyikapi dinamika perubahan sebagai akibat dari tuntutan zaman yang diwarnai oleh derasnya arus budaya global. Kebudayaan nasional yang diharapkan mampu sebagai katalisator dalam mengadopsi nilai-nilai universal yang luhur dan sekaligus sebagai filter terhadap masuknya budaya global yang bersifat negatif belum mampu berfungsi sebagaimana mestinya.

Lemahnya ketahanan budaya juga ditunjukkan oleh terjadinya gejala krisis identitas. Norma-norma lama semakin melemah, sementara norma baru belum terkonsolidasi dengan baik sehingga terjadi sikap ambivalensi dan disorientasi tata nilai. Disorientasi tata nilai yang terjadi bersamaan dengan tumbuhnya semangat kebebasan mengakibatkan pandangan permisif atau serba boleh. Hal tersebut berkembang secara berlebihan cenderung memicu konflik di berbagai bidang kehidupan.

Krisis yang berkepanjangan semakin melemahkan kepercayaan diri dan kebanggaan sebagai suatu bangsa, serta meningkatnya ketergantungan kepada pihak lain. Menipisnya semangat nasionalisme tersebut juga sebagai akibat dari lemahnya kemampuan bangsa dalam mengelola keragaman. Hal tersebut tercermin dari menguatnya sentimen antarkelompok yang berdampak pada terjadinya konflik sosial berkekerasan yang mengakibatkan korban jiwa, dan bahkan disintegrasi bangsa. United Nation for Indonesian Recovery (UNSFIR) melaporkan bahwa selama periode 1997-2004, konflik sosial yang terjadi di
Indonesia telah menelan sedikitnya 15 ribu orang tewas. Disintegrasi ditandai dengan lepasnya Timor Timur dari Indonesia menjadi Republik Timur Leste.

Keanekaragaman masyarakat Indonesia merupakan realitas obyektif yang tidak dapat dipungkiri. Keanekaragaman di satu sisi akan memberi warna positif pada sistem nilai budaya bangsa apabila terwujud dalam bentuk interaksi yang saling melengkapi, tetapi di sisi lain dapat menjadi sumber konflik apabila tidak dipahami dengan baik dan apalagi menjadikannya sebagai suatu unit dalam berkompetisi untuk memperebutkan sumberdaya ekonomi dan politik.

Konsepsi Bhinneka Tunggal Ika merupakan acuan dalam mengelola kemajemukan sehingga kemajemukan tersebut menjadi kekuatan bangsa. Cita-cita bersama untuk mewujudkan demokrasi menuntut adanya penghargaan terhadap keragaman budaya sehingga perlu adanya pengelolaan keragaman. Jika tidak dikelola dengan baik, tidak menutup kemungkinan akan terjadi persinggungan antarbudaya, agama dan etnis yang akan mendatangkan masalah bagi proses demokrasi. Dalam beberapa tahun terakhir, bangsa Indonesia dihadapkan pada kenyataan banyaknya konflik dan ketegangan yang dipicu oleh sentimen primordial tersebut.

Kepekaan terhadap pluralitas bangsa, baik dalam etnis, agama, budaya, hingga orientasi politik menjadi penting agar tumbuh sikap respek terhadap keragaman. Sikap respek tersebut harus menjadi 
bagian dari kurikulum pendidikan di berbagai jenjang baik di lembaga pendidikan pemerintah maupun swasta dan menjadi budaya baru menuju masyarakat yang multikultur. Upaya tersebut dilakukan dalam kerangka pembangunan karakter dalam menumbuhkembangkan masyarakat multikultur yang ditandai oleh sikap yang egalitarian, toleran dan demokratis.

Karakter adalah kumpulan tata nilai yang menuju pada suatu sistem, yang melandasi pemikiran, sikap, dan perilaku yang ditampilkan (Simon Philips, 2008). Doni Koesoema A (2007) memahami bahwa karakter sama dengan kepribadian. Kepribadian dianggap sebagai ciri, atau karakteristik, atau gaya, atau sifat khas dari diri seseorang yang bersumber dari bentukan-bentukan yang diterima dari lingkungan, misalnya lingkungan keluarga pada masa kecil dan juga bawaan seseorang sejak lahir.

Karakter menunjukkan bagaimana seseorang bertingkah laku. Apabila seseorang berperilaku tidak jujur, kejam, atau rakus, tentulah orang tersebut memanifestasikan perilaku buruk. Sebaliknya, apabila seseorang berperilaku jujur, suka menolong, tentulah orang tersebut memanifestasikan karakter mulia. Istilah karakter erat kaitannya dengan 'personality'. Seseorang baru bisa disebut orang yang berkarakter apabila tingkah lakunya sesuai kaidah moral. Sedangkan Imam alGhozali menganggap bahwa karakter lebih dekat dengan akhlak, yaitu spontanitas manusia dalam bersikap, atau melakukan perbuatan yang telah menyatu dalam diri manusia sehingga ketika muncul tidak perlu dipikirkan lagi.

Dari pendapat di atas dipahami bahwa karakter berkaitan dengan kekuatan moral, berkonotasi positif, bukan netral. Orang yang berkarakter adalah orang yang mempunyai kualitas moral tertentu yang positif. Dengan demikian, membangun karakter secara implisit mengandung arti membangun sifat atau pola perilaku yang didasari atau berkaitan dengan dimensi moral yang positif atau baik, bukan yang negatif atau buruk.

Peterson dan Seligman (Gedhe Raka, 2007) mengaitkan secara langsung antara karakter yang kuat dengan kebajikan. Karakter yang kuat dipandang sebagai unsur-unsur psikologis yang membangun kebajikan. Salah satu kriteria utamanya adalah bahwa karakter tersebut berkontribusi besar dalam mewujudkan sepenuhnya potensi dan cita-cita seseorang dalam membangun kehidupan yang baik, yang bermanfaat bagi dirinya, orang lain, dan bangsanya.

Karakter bangsa sebagai kondisi watak yang merupakan identitas bangsa atau identitas nasional. Identitas nasional dapat diartikan sebagai jatidiri nasional atau kepribadian nasional. Jatidiri nasional suatu bangsa tentu berbeda dengan jatidiri bangsa lain. Ini disebabkan oleh perbedaan latar belakang sejarah, kebudayaan, maupun geografi. Jatidiri nasional bangsa Indonesia terbentuk karena rakyat Indonesia memiliki pengalaman sejarah yang sama. Pengalaman 
sejarah yang sama itu dapat menumbuhkan kesadaran kebangsaan yang kemudian pada ujungnya melahirkan identitas nasional (Chamim, 2003).

Lahirnya identitas nasional suatu bangsa tidak dapat dilepaskan dari dukungan faktor objektif, yaitu faktor-faktor yang berkaitan dengan geografis-ekologis dan demografis; dan faktor subjektif, yaitu faktorfaktor historis, politik, sosial dan kebudayaan yang dimiliki bangsa itu (Joko Suryo, 2002).

Karakter suatu bangsa akan berkembang berdasarkan pengalaman dalam sejarah bangsa. Suatu bangsa tidak dapat dilepaskan dari pengalaman kehidupan masyarakatnya. Aktivitas masyarakat dalam perkembangan sejarahnya banyak berhubungan dengan pertumbuhan negara bangsa sehingga karakter masyarakat merupakan satu elemen dari suatu karakter bangsa atau kepribadian bangsa.

Karakter suatu bangsa akan terbangun atau tidak sangat tergantung kepada bangsa itu sendiri. Apabila bangsa tersebut memberikan perhatian yang cukup untuk membangun karakter, maka akan terciptalah bangsa yang berkarakter. Apabila sekolah dapat memberikan pembangunan karakter kepada para muridnya, maka akan tercipta pula murid yang berkarakter. Demikian pula sebaliknya.

Pembentukan karakter merupakan aspek penting dalam pendidikan. Rumusan pendidikan dalam Pasal 1 Ayat (1) Undang-undang Republik Indonesia Nomor 20 Tahun 2003 tentang Sistem Pendidikan
Nasional secara tegas menekankan pentingnya pembentukan karakter, "Pendidikan adalah usaha sadar dan terencana untuk mewujudkan suasana belajar dan proses pembelajaran agar peserta didik secara aktif mengembangkan potensi dirinya untuk memiliki kekuatan spiritual keagamaan, pengendalian diri, kepribadian, kecerdasan, akhlak mulia, serta keterampilan yang diperlukan dirinya, masyarakat, bangsa dan negara."

Komaruddin Hidayat (2006) mengemukakan bahwa pendidikan yang berorientasi pada pembangunan karakter bangsa merupakan salah satu upaya strategis di tengah krisis identitas dan peradaban bangsa. Pendidikan ini menjadikan peserta didik sebagai subjek melalui cara-cara yang demokratis, partisipatif, kritis, dan menantang bagi aktualisasi diri mereka. Dalam konteks ini, pembelajaran sejarah yang multikultural sangat relevan dalam kerangka pembangunan karakter bangsa.

Pembelajaran sejarah yang multikultural ditandai dengan berbagai sikap pendidik yang menghargai setiap perbedaan latar belakang sejarah, etnik atau budaya di kalangan peserta didik. Pendidik menghindari ucapan, perilaku atau sikap yang mengarah pada stereotip dengan mengelompokkan "kita" dan "mereka". Pendidik juga melakukan seleksi bahan pembelajaran yang mewakili secara adil setiap wilayah bahasa, kultur atau etnik (Rochiati Wiriaatmadja, 1997). 
Pendekatan multikultural dalam pembelajaran sejarah akan membawa peserta didik kepada perkembangan dirinya dalam "berbagi kemanusiaan", mencoba memahami diri sendiri dan orang lain, mempelajari perbedaan dan persamaan dari jaman ke jaman serta menghormatinya, mempertanyakan perlakuan stereotipikal dirinya dan orang lain, mampu membedakan fakta dan dugaan, menyadari kompleksitas sejarah dan sebabsebabnya, menyadari bahwa dalam kehidupan ada kalanya faktor kebetulan atau irrasionalitas terjadi, serta kuatnya peranan gagasan atau integritas seseorang dalam sejarah.

Untuk itu diperlukan metode pembelajaran yang mampu merangsang dan mengajak peserta didik untuk dapat belajar. Maka sudah selayaknya apabila pendidik menyadari kelebihan dan kelemahan dari metode yang digunakan berdasarkan kerangka teori dan konseptual yang ada. Fungsi metode adalah sebagai jembatan, jembatan antara peserta didik dan materi pelajaran yang sedang dipelajari. Dan agar pembelajaran sejarah tidak menjadi bahan hafalan, diperlukan metode yang berorientasi pada masalah. Peserta didik dihadapkan pada masalah tertentu agar dapat belajar secara kritis. Bahkan apabila perlu diberi kesempatan untk melakukan pengembaraan intelektual melalui penjelajahan berbagai peristiwa sejarah yang satu ke yang lain.

Satu hal yang penting dicatat bahwa dalam era otonomi pendidikan dan otonomi sekolah dewasa ini, pemanfaatan sejarah lokal ditingkat pendidikan manapun akan memungkinkan peserta didik dalam mempelajari sejarah dapat beresonansi dengan aspek eigenwelt yang dimiliki (Hariyono, 1995). Peserta didik tidak langsung dibawa pada suatu peristiwa sejarah yan jauh dengan pengalaman sehari-hari.

Pemaparan sejarah secara kontekstual sangat penting untuk dibicarakan. Baru setelah peserta didik paham akan berbagai peristiwa sejarah di masyarakat sekitarnya, peluang untuk mengajak memahami peristiwa sejarah di daerah lain niscaya akan relatif lebih mudah. Melalui kajian sejarah lokal, peserta didik dirangsang untuk dapat melihat proses integrasi nasional sebagai suatu peristiwa sejarah. Untuk mengajak keterlibatan peserta didik dalam memahami dan mengkaji sejarah lokal, pendidik seyogyanya mengetahui beberapa aspek sejarah lokal, seperti dalam buku yang disunting oleh Taufik Abdullah (1985) berjudul "Sejarah Lokal di Indonesia". Demikian pula untuk dapat mengajak peserta didik belajar merekonstruksi sejarah di masyarakat sekitarnya, pemanfaatan metode sejarah lisan dapat membantu.

\section{Penutup}

Masyarakat Indonesia yang multikultur memerlukan pendidikan yang multikultural. Pendidikan yang multikultural merupakan pendidikan yang berwawasan keragaman kebudayaan. Pendidikan multikultural 
harus diperhatikan oleh para pengembang kurikulum dan pembelajaran. Kurikulum yang multikultural adalah kurikulum yang mengakomodasi perbedaan latar belakang peserta didik, memanfaatkan kebudayaan sebagai sumber muatan dan titik berangkat bagi pengembangan kebudayaan itu sendiri, pemahaman terhadap kebudayaan orang lain, toleransi, membangkitkan semangat kebangsaan peserta didik dan mengembangkan perilaku yang lebih beretika serta memanfaatkan kebudayaan peserta didik sebagai bagian dari pembangunan peserta didik. Dengan cara demikian, pembelajaran sejarah akan berperan penting bagi pembangunan karakter bangsa.

Pembelajaran sejarah yang multikultural ditandai dengan berbagai sikap guru yang menghargai setiap perbedaan latar belakang sejarah, etnik atau budaya di kalangan peserta didik. Metode pembelajaran yang diterapkan mampu merangsang dan mengajak peserta didik untuk dapat belajar. Dalam konteks ini, pemanfaatan sejarah lokal akan memungkinkan peserta didik dalam mempelajari sejarah. Peserta didik tidak langsung dibawa pada suatu peristiwa sejarah yan jauh dengan pengalaman seharihari. Melalui pemaparan sejarah secara kontekstual, peserta didik akan memahami berbagai peristiwa sejarah di masyarakat sekitarnya, sehingga peluang untuk mengajak memahami peristiwa sejarah di daerah lain dan di tingkat nasional niscaya akan relatif lebih mudah. Melalui kajian sejarah lokal, peserta didik dirangsang untuk dapat melihat proses integrasi nasional sebagai suatu peristiwa sejarah. 


\section{Daftar Pustaka}

Alo Liliweri. 2005. Prasangka dan Konflik: Komunikasi Lintas Budaya Masyarakat Multikultur. Yogyakarta: LKiS.

Azyumardi Azra. 2003. Pendidikan Multikultural, Membangun Kembali Indonesia Bhinneka Tunggal Ika dalam Tsaqofah, "Menggagas Pendidikan Multikultural", vol. I, nomor 2, Tahun 2003.

Daniel T. Sparringa. 2003. Multikulturalisme dalam Multiperspektif di Indonesia. Surabaya: Forum Rektor Simpul Jawa Timur Universitas Surabaya.

Djoko Santoso. 2008. "Ketahanan Negara dan Wawasan kebangsaan Menghadapi Tantangan Global," Makalah disampaikan pada Simposium Nasional Peringatan Satu Abad Kebangkitan Nasional, 19 Mei 2008. Yogyakarta: UGM, Pemda DIY, Kagama.

Fuad Abdul Hamid. 1999. "Pendidikan Multikultural dalam Konteks Pengembangan serta Implementasi Kurikulum Sekolah di Indonesia", dalam Konvensi Nasional Pendidikan Indonesia II: Kurikulum untuk Abad ke-21. Jakarta: Gramedia.

Hariyono. 1995. Mempelajari Sejarah Secara Efektif. Jakarta: Pustaka Jaya.

H.A.R. Tilaar. 2002. Perubahan Sosial dan Pendidikan: Pengantar Pedagogik Transformatif untuk Indonesia, Jakarta: Grasindo.

Hasan, S. Hamid. 1996. Pendekatan Multikultural untuk Penyem- purnaan Kurikulum Nasional. Bandung: Universitas Pendidikan Indonesia.

Huntington, Samuel. P. 2000. Benturan Antarperadaban dan Masa Depan Politik Dunia. Yogyakarta: Qalam.

Joko Suryo. 2002. Pembentukan Identitas Nasional, Makalah pada Seminar Terbatas Pengembangan Wawasan tentang Civic Education. Yogyakarta: LP3 UMY.

Koentjaraningrat (ed.). 2002. Manusia dan Kebudayaan di Indonesia. Jakarta: Djambatan.

Komaruddin Hidayat. 2006. dalam A. Ubaedah dan Abdul Rozak (peny.), Demokrasi, Hak Asasi Manusia, dan Masyarakat Madani. Jakarta: CCE UIN Syarif Hidayatullah.

Lombard, Denys. Nusa Jawa: Silang Budaya. Bandung: Remaja Rosda Karya.

Mochtar Buchori, Pendidikan Multikultural, dalam KOMPAS Edisi 4 Maret 2007.

Mulder, Niels. 2000. Individu, Masyarakat dan Sejarah, Kajian Kritis Buku-buku Pelajaran Sekolah di Indonesia, terjemah A. Widyamartaya. Yogyakarta: Kanisius

Nasikun, 1984, Sistem Sosial Indonesia. Jakarta: Rajawali.

Ricklefs, M.C. 1998. Sejarah Indonesia Modern, terjemah Dharmono Hardjowidjono. Yogyakarta: Gadjahmada University Press.

Rochiati Wiriaatmadja, Landasan Filosofis Kurikulum Pembelajaran Sejarah (SMU), Tantangan dan Harapan, 
Makalah disajikan dalam Simposium Pembelajaran Sejarah Ditjen Kebudayaan, 2528 Desember 1997 di Bogor Jawa Barat.

Sartono Kartodirdjo. 1999. Ideologi dan Teknologi dalam Pembangunan Bangsa: Eksplorasi Dimensi Historis dan SosioKultural. Jakarta: Pabelan Jayakarta.

S. Hamid Hasan. 2000. Pendekatan Multikultural Untuk Penyempurnaan Kurikulum Nasional. Konvensi Nasional Pendidikan Indonesia II: Kurikulum untuk Abad ke-21 dalam Jurnal Pendidikan dan Kebudayaan, Jakarta, Edisi Bulan JanuariNovember 2000.

Suyatno Kartodirdjo. 2000. "Revitalisasi Bhineka Tunggal Ika Tan Hana Dharma Mangrwa dalam Rangka Menuju Indonesia Baru", Makalah, disajikan dalam Sarasehan Membangun Wawasan Kebangsaan melalui Revitalisasi Budaya diselenggara-kan oleh Keraton Kasunanan, Pura Mangkunegaran, PII dan HKMN Suryasumirat, di Surakarta, 5 Agustus 2000.

Taufik Abdullah. 1985. Sejarah Lokal di Indonesia. Yogyakarta: Gadjahmada University Press.

Wertheim, W.F. 1999. Masyarakat Indonesia dalam Transisi, Kajian Perubahan Sosial. Terjemah Misbah Zulfa Ellizabet. Yogyakarta: Tiara Wacana. 